\title{
Maciej Drzonek*
}

\section{WSKAŹNIKI BADANIA POZYCJI POLITYCZNEJ „WIECZNYCH PREZYDENTÓW"}

\section{Wstęp}

W zasadzie nie ma wątpliwości, że na poziomie gmin i miast toczy się rywalizacja polityczna, w której biorą udział różni aktorzy. Jest ona wynikiem ścierania się różnych pomysłów na sposób funkcjonowania lokalnych społeczności i zarządzania nimi przez ich liderów, które proponują jej uczestnicy. Można wyodrębnić dwie skrajne kategorie aktorów lokalnej rywalizacji politycznej - partie polityczne oraz ugrupowania pozapartyjne. Pomiędzy nimi oczywiście występują ugrupowania, które trudno zaliczyć do partyjnej, jak i pozapartyjnej kategorii. Jakkolwiek by dokonywać kategoryzowania aktorów rywalizacji na poziomie społeczności lokalnych - tu zdania badaczy są podzielone ${ }^{1}$ - to nie ma wątpliwości, że aktorzy ci rywalizują na lokalnych scenach politycznych. Można przyjąć za Wojciechem Kostką, że na lokalnych scenach politycznych są odzwierciedlane ,zachowania jednostek i grup społecznych, które uczestniczą w sprawowaniu władzy przez samorząd gminny (powiatowy lub wojewódzki) albo starają się gmail.com

* dr hab. Maciej Drzonek prof. US, Uniwersytet Szczeciński, e-mail: maciej.drzonek@

1 T. Gajowniczek, Rywalizacja $w$ wyborach powiatowych województwa warmińsko-mazurskiego, w: Doświadczenia i perspektywy rozwoju samorzadu terytorialnego i zawodowego, red. P. Antkowiak, Wydawnictwo Adam Marszałek, Toruń 2014, s. 121-134; R. Glajcar, Podmioty rywalizacji wyborczej w miastach na prawach powiatu (na przyktadzie województwa ślaskiego), w: Wybory samorządowe 2010, red. M. Kolczyński, W. Wojtasik, Katowice 2011, s. 126; P. Swianiewicz, Bezpartyjni radni w samorzadach gminnych, „Samorząd Terytorialny” 2010, nr 11, s. 28. 
wpływać na decyzje podejmowane przez organy samorządu gminnego"2. Z takiej interpretacji tego pojęcia wynika, że, po pierwsze, na poziomie lokalnym mamy do czynienia z rywalizacją o charakterze politycznym ${ }^{3}$, a po drugie - podmioty tej rywalizacji mogą mieć różny charakter. Skoro konkurowanie przyjmuje postać polityczną, to niewątpliwie jego podstawowym punktem odniesienia jest władza. Co do tego również nie ma poważniejszych zastrzeżeń ${ }^{4}$, choć pojawiają się wątpliwości, czy władza polityczna takąż może być nazywana. Przykładowo, nad tą kwestią zastanawiał się Andrzej Antoszewski, który zwracał uwagę, że władzę polityczną wykonuje ,przede wszystkim ten, kto jest w stanie określić, w jaki sposób można ją osiągnąć, jak należy ją sprawować i w jakich warunkach można ją utracić”, a możliwość określania „zasad dostępu do władzy jest instrumentem upodmiotowienia (bądź uprzedmiotowienia) zbiorowości, nad którą jest sprawowana"s.

Tymczasem instytucje wybieralne na poziomie lokalnym nie są władne do podejmowania decyzji o zasadach tworzenia ich samych, nie określają swoich struktur i kompetencji. Co więcej, organy samorządowe nie mają możliwości określania reguł, na podstawie których organy te są obsadzane w wyniku rywalizacji wyborczej. Stąd wynika trudność w uznaniu władzy lokalnej za polityczną w takim samym znaczeniu, jak to się czyni w odniesieniu do władzy państwa. Ponieważ jednak władza lokalna ma pewne atrybuty władztwa politycznego (m.in. jest formą walki z władzą centralną, jest areną rywalizacji partii politycznych), to zdaniem A. Antoszewskiego władzę samorządową należy uznać za „władzę polityczną o ograniczonym charakterze"6. De facto na podobnym stanowisku stanął również Waldemar Wojtasik?

Nawet biorąc pod uwagę powyżej zaprezentowane ograniczenia władzy lokalnej, nie można zaprzeczyć, że jest ona przedmiotem rywalizacji o charakterze politycznym - tezę taką można bowiem poczynić także na podstawie jeszcze 2008, s. 93.

2 W. Kostka, Instytucjonalizacja partii politycznych w społecznościach miejskich, Toruń

3 O wzorcach rywalizacji zob. R. Matyja, Rywalizacja polityczna w Polsce, Ośrodek Myśli Politycznej, Wyższa Szkoła Informatyki i Zarządzania, Kraków-Rzeszów, s. 18-32.

4 Choć są oczywiście różne stanowiska wobec tego czym jest władza, zwłaszcza gdy chodzi o rozgraniczenie tego terminu od pojęcia wpływu, zob. np. R.A. Dahl, B. Stinebrickner, Współczesna analiza polityczna, Scholar, Warszawa 2007, s. 29-42.

5 A. Antoszewski, Istota władzy samorządowej, w: Polityka lokalna-właściwości, determinanty, podmioty, red. E. Ganowicz, L. Rubisz, Wydawnictwo Adam Marszałek, Toruń 2008, s. 52.

6 Ibidem, s. 54-57.

7 W. Wojtasik, Funkcje wyborów w III RP, Wydawnictwo Uniwersytetu Śląskiego, Katowice 2012, s. 236. 
innej przesłanki. Podmiotami rywalizacji na poziomie lokalnym są m.in. partie polityczne, dla których cele tej rywalizacji są de facto dwa - udział w strukturach władzy lokalnej oraz możliwość zdobycia lub utrzymania stanowiska w organach władzy centralnej. Cel pierwszy ma zatem do pewnego stopnia charakter taktyczny, jego osiągnięcie jest użyteczne dla osiągnięcia celu drugiego, który dla partii jest strategiczny, nadrzędny. Organy władzy centralnej są bez wątpienia uosobieniem władzy politycznej, a skoro partie polityczne wykorzystują do jej zdobywania instytucje władzy lokalnej, to tym samym już władza lokalna staje się ,upolityczniona”, a z pewnością rywalizowanie na poziomie lokalnym ma znamiona ,polityczne”.

Celem dalszych rozważań, na podstawie analizy reelekcji włodarzy miast na prawach powiatów, jest wyodrębnienie i uogólnienie wskaźników, które pozwalałyby na określenie ich pozycji politycznej ${ }^{8}$. Można bowiem postawić tezę, że im silniejsza jest pozycja polityczna prezydenta miasta, tym bardziej prawdopodobna jest jego reelekcja w kolejnych wyborach.

Termin ,pozycja polityczna” prezydenta miasta jest tutaj rozumiany jako specyficzne położenie w strukturze lokalnego systemu politycznego (na lokalnej scenie politycznej), które wpływa na stopień efektywności podejmowanych decyzji politycznych 9 .

Z kolei określenie ,wieczny prezydent” jest odnoszone do prezydentów miast-powiatów, którzy byli wybierani we wszystkich dotychczasowych elekcjach bezpośrednich (a więc lat 2002-2014). Niniejsza analiza jest zatem ograniczona tylko do miast na prawach powiatu, w których ich mieszkańcy w czterech kolejnych wyborach powierzali fotel włodarza miasta tym samym osobom. Po wyborach w 2014 roku mamy 17 takich miast ${ }^{10}$. W większości wieczni

8 Szerzej o reelekcjach prezydentów miast w latach 2002-2010 zob. M. Drzonek, Reelekcje prezydentów miast w wyborach bezpośrednich w Polsce, Dante, Kraków 2013.

9 Decyzja polityczna jest interpretowana jako ,akt nielosowego (świadomego) wyboru działania lub zaniechania politycznego", zob. Z.J. Pietraś, Decydowanie polityczne, Wydawnictwo Naukowe PWN, Warszawa-Kraków 1998, s. 127. Biorąc pod uwagę efektywność decyzji politycznych należy pamiętać o powiązaniu jej raczej z procesem ich optymalizowania, a nie z dążeniem do podejmowania decyzji optymalnych. Uznanie decyzji za „optymalną” jest bowiem zawsze uzależnione od czasu, w którym to uznanie następuje oraz punktu widzenia podmiotu, który dokonuje oceny decyzji, zob. ibidem, s. 128-129.

10 Są to: Bielsko-Biała (Jacek Krywult, KWW), Gdańsk (Paweł Adamowicz, PO), Gdynia (Wojciech Szczurek, KWW), Gliwice (Zygmunt Frankiewicz, KWW), Jaworzno (Paweł Silbert, KWW), Kielce (Wojciech Lubawski, KWW), Kraków (Jacek Majchrowski, KWW), Krosno (Piotr Przytocki, KWW), Legnica (Tadeusz Krzakowski, KWW), Przemyśl (Robert Choma, KWW), Rzeszów (Tadeusz Ferenc, KWW), Sopot (Jacek Karnowski, KWW), Świnoujście (Janusz Żmurkiewicz, SLD), Torun (Michał Zaleski, KWW), Tychy (Andrzej Dziuba, KWW), Wrocław (Rafał Dutkiewicz, KWW), Żory (Waldemar Socha, KWW). 
prezydenci startowali z komitetów wyborczych wyborców, bo tylko prezydenci Gdańska i Świnoujścia zawsze reprezentowali tę samą partię ${ }^{11}$.

\section{Wskaźniki}

Wśród wskaźników pozwalających określić pozycję polityczną prezydenta miasta można wyodrębnić czynniki wynikające bezpośrednio z jego aktywności oraz kryteria wskazujące na tę pozycję, które tylko pośrednio są efektem działań podejmowanych przez włodarza miasta. Do bezpośrednich indykatorów będą zaliczane procent poparcia uzyskanego w pierwszej turze głosowania (P1), wskaźnik intensyfikacji rywalizacji wyborczej pomiędzy prezydentem a jego głównym rywalem (WR1) oraz wskaźnik związku z zapleczem (WZ). Jako pośrednie czynniki pozwalające określić pozycję polityczną prezydenta miasta uznano wskaźnik intensyfikacji rywalizacji wyborczej pomiędzy komitetem prezydenta a komitetem jego największego rywala w wyborach do rady miasta (WR1K), pozycja jego komitetu w radzie miasta (zajmowane w strukturze rady miejsce ze względu na liczbę mandatów - PRM) oraz procent mandatów zdobytych w radzie przez komitet prezydencki (MRM).

Biorąc pod uwagę pierwszy z wymienionych wyżej wskaźników - wielkość poparcia otrzymanego w pierwszej turze głosowania - należy przede wszystkim zauważyć, że istotne znaczenie ma przekroczenie pułapu 50\% głosów. W warunkach obowiązujących w Polsce przepisów wyborczych właśnie osiągnięcie takiego pułapu zdobytych głosów pozwala uzyskać stanowisko będące przedmiotem rywalizacji wyborczej. Zastosowanie wskaźnika P1 przede wszystkim pozwala zatem na wyodrębnienie dwóch grup prezydentów - tych którzy wygrali w pierwszej turze głosowania (przekroczyli limit 50\% głosów) oraz tych, którzy zmuszeni byli do udziału w rywalizacji w drugiej turze głosowania. Oczywiście możliwość zwycięstwa już w pierwszym głosowaniu jest uwarunkowane od wielu zmiennych, niezależnych od biorącego udział w rywalizacji prezydenta (liczba kontrkandydatów, ich proweniencja polityczna, dominujące preferencje

11 Sytuacja jest jednak bardziej wysublimowana - część prezydentów formalnie startuje z KWW, które w praktyce jest powiązane z jakąś partią polityczną. Szerzej o tzw. niby-bezpartyjności wiecznych prezydentów zob. np.: A. Gendźwiłł, T. Żółtak, Bezpartyjność w powolnym odwrocie. Analiza rozpowszechniania bezpartyjności $w$ wyborach lokalnych $w$ Polsce $w$ latach 2002-2010, „Studia Regionalne i Lokalne” 2012, nr 1, s. 108-109; P. Swianiewicz, Bezpartyjni radni w samorzadach gminnych, „Samorząd Terytorialny” 2010, nr 11, s. 23; M. Drzonek, Partie w masce niepartyjności - uwagi o komitetach niby-bezpartyjnych w elekcjach prezydentów miast, w: Partyjnie czy bezpartyjnie? Szkice o zdobywaniu władzy lokalnej, red. idem, Wydawnictwo Naukowe Uniwersytetu Szczecińskiego, Szczecin 2014, s. 97-111. 
polityczne mieszkańców itp.). Jednak właśnie z uwagi na występowanie tego typu czynników, tym większego znaczenia nabiera pokonanie konkurentów przez przekonanie do siebie ponad połowy wyborców ${ }^{12}$. Z kolei w grupie zwycięzców „ponadpięćdziesięcioprocentowych” można wyróżnić krąg „przodowników”, których poparcie jest wyższe od średniej dla tej grupy.

Wskaźnik poparcia można też odnieść do średniej wielkości w danym roku. W 2002 roku wyniosła ona 37,48\%, a w kolejnych wyborach odpowiednio: 2006 $-61,58 \% ; 2010-60,68 \% ; 2014-53,82 \%$.

Tabela 1. Wieczni prezydenci z 2014 roku, którzy wygrywali wybory w I turze

\begin{tabular}{|c|c|c|c|c|c|}
\hline Miasto & Prezydent & 2002 & 2006 & 2010 & 2014 \\
\hline Bielsko B. & J. Krywult & - & 1 & 1 & - \\
\hline Gdańsk & P. Adamowicz & - & 1 & 1 & - \\
\hline Gdynia & W. Szczurek & 1 & 1 & 1 & 1 \\
\hline Gliwice & Z. Frankiewicz & - & 1 & - & 1 \\
\hline Jaworzno & P. Silbert & - & - & 1 & - \\
\hline Kielce & W. Lubawski & - & 1 & 1 & 1 \\
\hline Kraków & J. Majchrowski & - & - & - & - \\
\hline Krosno & P. Przytocki & - & 1 & 1 & 1 \\
\hline Legnica & T. Krzakowski & - & 1 & 1 & - \\
\hline Przemyśl & R. Choma & - & 1 & 1 & - \\
\hline Rzeszów & T. Ferenc & - & 1 & 1 & 1 \\
\hline Sopot & J. Karnowski & 1 & 1 & - & 1 \\
\hline Świn. & J. Żmurkiewicz & - & 1 & 1 & 1 \\
\hline Toruń & M. Zaleski & - & 1 & 1 & 1 \\
\hline Tychy & A. Dziuba & - & - & 1 & 1 \\
\hline Wrocław & R. Dutkiewicz & - & 1 & 1 & - \\
\hline Żory & W. Socha & - & - & 1 & - \\
\hline
\end{tabular}

Źródło: opracowanie własne na podstawie danych zawartych na www.pkw.gov.pl.

Z powyższego zestawienia wynika, że tylko jeden wieczny prezydent wygrywał zawsze w pierwszej turze (W. Szczurek w Gdyni), a w co najmniej trzech kolejnych elekcjach poparcie powyżej 50\% uzyskiwało pięciu włodarzy (W. Lubawski w Kielcach, P. Przytocki w Krośnie, T. Ferenc w Rzeszowie,

12 Warto na marginesie zwrócić uwagę, że występowanie w elekcji prezydenckiej małej liczby kontrkandydatów względem urzędującego prezydenta zazwyczaj jest wynikiem silnej pozycji włodarza miasta. Konkurencyjne ugrupowania występujące na lokalnej scenie politycznej (zarówno partyjne, jak i pozapartyjne) obawiając się porażki, decydują się na absencję w rywalizacji prezydenckiej i partycypują jedynie w walce o mandaty radnych. 
J. Żmurkiewicz w Świnoujściu i M. Zaleski w Toruniu). Jak można zauważyć, powiaty grodzkie, w których ci sami prezydenci otrzymywali poparcie na poziomie większości bezwzględnej łączy to, że pod względem demograficznym należą one do miast małych (Świnoujście, Krosno - poniżej 50 tys.) oraz około dwustutysięcznych (Rzeszów, Kielce, Toruń, Gdynia).

Tabela 2. Poparcie dla wiecznych prezydentów w wyborach w latach 2002-2014

(I tury - P1). Zaznaczono wartości powyżej średniej poparcia w danym roku

\begin{tabular}{|l|l|l|l|l|}
\hline \multicolumn{1}{|c|}{ Miasto } & 2002 & 2006 & 2010 & 2014 \\
\hline Bielsko Biała & 15,11 & $\mathbf{6 8 , 6 9}$ & $\mathbf{7 5 , 7 1}$ & 47,96 \\
\hline Gdańsk & 37,46 & 60,87 & 53,78 & 46,05 \\
\hline Gdynia & $\mathbf{7 7 , 2 6}$ & $\mathbf{8 5 , 8 1}$ & $\mathbf{8 7 , 3 9}$ & $\mathbf{7 9 , 0 2}$ \\
\hline Gliwice & $\mathbf{4 5 , 2 2}$ & 55,97 & 47,62 & $\mathbf{5 5 , 7 3}$ \\
\hline Jaworzno & 37,20 & 42,00 & $\mathbf{6 4 , 4 6}$ & 45,58 \\
\hline Kielce & 35,18 & $\mathbf{7 1 , 9 8}$ & 58,66 & $\mathbf{5 5 , 6 9}$ \\
\hline Kraków & 21,18 & 42,31 & 40,78 & 39,18 \\
\hline Krosno & 24,57 & $\mathbf{7 3 , 7 5}$ & $\mathbf{7 6 , 6 2}$ & $\mathbf{6 9 , 9 1}$ \\
\hline Legnica & $\mathbf{4 5 , 8 8}$ & 57,49 & $\mathbf{6 6 , 6 5}$ & 44,69 \\
\hline Przemyśl & 28,98 & $\mathbf{6 5 , 6 0}$ & 52,15 & 27,50 \\
\hline Rzeszów & $\mathbf{4 4 , 3 9}$ & $\mathbf{7 6 , 5 9}$ & 53,25 & $\mathbf{6 6 , 3 1}$ \\
\hline Sopot & $\mathbf{5 6 , 3 4}$ & $\mathbf{6 3 , 4 8}$ & 42,50 & 53,37 \\
\hline Świnoujście & 29,93 & 51,15 & 59,53 & $\mathbf{6 2 , 5 0}$ \\
\hline Toruń & 25,87 & $\mathbf{7 0 , 6 2}$ & $\mathbf{6 5 , 5 9}$ & $\mathbf{7 0 , 2 7}$ \\
\hline Tychy & 29,31 & 40,84 & 55,94 & $\mathbf{6 4 , 7 6}$ \\
\hline Wrocław & $\mathbf{4 2 , 1 1}$ & $\mathbf{8 4 , 5 3}$ & $\mathbf{7 1 , 6 3}$ & 42,37 \\
\hline Żory & $\mathbf{4 1 , 0 9}$ & 35,23 & 59,26 & 44,10 \\
\hline Średnia & $\mathbf{3 7 , 4 8}$ & $\mathbf{6 1 , 5 8}$ & $\mathbf{6 0 , 6 8}$ & $\mathbf{5 3 , 8 2}$ \\
\hline
\end{tabular}

Źródło: opracowanie własne na podstawie danych zawartych na www.pkw.gov.pl.

Tylko trzech wiecznych prezydentów zawsze osiągało wyższe wyniki podczas reelekcji niż średnia dla danego roku (W. Szczurek, P. Przytocki i M. Zaleski). Na podstawie zestawienia zawartego w tabeli 2 widać również, że średnie poparcie dla wiecznych prezydentów najwyższą wartość osiągnęło w 2006 roku (pierwsza reelekcja w wyborach bezpośrednich), w 2010 roku było nieznacznie niższe, a w elekcji z 2014 roku spadło dość znacząco. Interesujący jest w tym kontekście przypadek prezydenta Wrocławia, który od 2002 do 2010 roku osiągał zawsze wyniki powyżej średniej, a w 2014 roku nie tylko otrzymał poparcie poniżej średniej dla 17 wiecznych prezydentów, ale również miał najniższy wynik po prezydentach Przemyśla i Krakowa. Analiza poparcia wiecznych prezydentów 
w kolejnych wyborach pokazuje ponadto, że tylko dwóch z nich odnotowało wzrost poparcia w każdych kolejnych wyborach (Świnoujście i Tychy), przy czym w obydwu przypadkach włodarze tych miast uzyskali poparcie powyżej średniej tylko raz - w 2014 roku.

Interesującym indykatorem pokazującym realną pozycję prezydenta jest wskaźnik intensyfikacji rywalizacji wyborczej pomiędzy nim a jego głównym rywalem (WR1), który jest obliczany na podstawie różnicy poparcia (w \%) prezydenta i jego głównego rywala. Dzięki obserwacji tego wskaźnika można określić dystans jaki dzieli włodarza od jego głównego rywala. Na wstępie warto jednak podkreślić, że jest on obliczany na podstawie wartości poparcia osiąganego przez obydwu konkurentów w pierwszej turze głosowania. Oznacza to, o czym należy pamiętać, że teoretycznie wartość WR1 może być ujemna. Dzieje się tak wówczas, gdy włodarz przegrywa rywalizację w I turze głosowania, a w drugiej pokonuje rywala. Elekcje lat 2002-2014 pokazały, że możliwość taka w praktyce rzeczywiście się zdarza ${ }^{13}$.

Analizując WR1 można zauważyć, że tylko nielicznym włodarzom miast na prawach powiatu udawało się osiągnąć jego wartość na poziomie ponad 50. Przyjęto zatem, że taki pułap wskaźnika rywalizacyjności wzmacnia pozycję włodarza - im rywalizacyjność w wyborach prezydenckich jest większa (różnica poparcia między konkurentami jest niewielka), tym pozycja zwycięzcy wydaje się być słabsza. Poniżej, w tabeli 3 zestawiono wartości WR1 w rozbiciu na poszczególne wybory, podając zarazem wartości uśrednione dla każdych wyborów.

Porównanie danych zebranych w tabeli 3 pozwala zauważyć, że średnia wartość WR1 najniższy poziom miała w pierwszych wyborach bezpośrednich $(12,38)$, co jest związane z tym, że wówczas startowało najwięcej kandydatów ${ }^{14}$. W 2006 roku wartość ta osiągnęła najwyższy poziom $(41,93)$ i w kolejnych dwóch wyborach zmniejszała się. Podobną, spadkową tendencję widać w przypadku danych dotyczących poparcia, które zebrano w tabeli 2. Co więcej, kiedy porówna się dane z obydwu tabel, to widać daleko idącą paralelność wartości P1 i WR1 powyżej średnich dla tych samych prezydentów. Tylko w przypadku pięciu miast

13 Do sytuacji takiej doszło w 2002 r. w Bielsku-Białej, Kielcach, Krakowie i Krośnie. Trzeba jednak podkreślić, iż WR1 nie miał wartości ujemnej podczas reelekcji żadnego z wiecznych prezydentów, a więc w latach 2006-2014.

14 Wedle danych GUS w 2002 r. o fotel prezydenta miasta (106 miast, w tym 65 mnpp) średnio ubiegało się 7,4 kandydatów, a w kolejnych latach średnia ta zmniejszała się (choć miast takich było 107) - w 2006 r. - 6,1 kandydatów, a w 2010 r. - 5,5 kandydatów, za: Mały Rocznik Statystyczny Polski 2003, Warszawa 2003, s. 75; Mały Rocznik Statystyczny Polski 2008, Warszawa 2008, s. 7; Rocznik statystyczny Rzeczypospolitej Polskiej 2012, GUS, Warszawa 2012, s. 125. 
odnotowano pewne odstępstwa: w Jaworznie w 2010 roku wartość P1 była wyższa od średniej, a WR1 $(28,92)$ była niższa od średniej $(39,79)$ aż o 10,87 ; w tym samym roku w Kielcach nastąpiła odwrotna sytuacja - WR1 osiągnęła wartość powyżej średniej, a P1 - o 2,02 poniżej średniej; w Sopocie w 2006 roku P1 przewyższyła średnią, a WR1 znalazła się na poziomie poniżej średniej (o 3,81); w Świnoujściu w 2010 roku wartość P1 była niższa od średniej o 1,15; w Żorach w 2002 roku odnotowano znacząco niższą wartość WR1 $(0,98)$ od średniej dla tego roku (12,38), a z kolei w 2010 roku P1 znalazła się poniżej średniej (o 1,42). Różnice pomiędzy wartościami powyżej średnich P1 i WR1 są jak widać niewielkie, ponieważ z reguły jeśli włodarz miasta osiąga ponadprzeciętne poparcie, to jednym z powodów jest mała rywalizacyjność na lokalnej scenie politycznej.

Tabela 3. Wartości WR1 w elekcjach wiecznych prezydentów w latach 2002-2014 (I tury)

\begin{tabular}{|l|c|c|c|c|}
\hline \multicolumn{1}{|c|}{ Miasto } & 2002 & 2006 & 2010 & 2014 \\
\hline Bielsko Biała & $-4,12$ & $\mathbf{5 7 , 9 8}$ & $\mathbf{6 6 , 2 4}$ & 24,64 \\
\hline Gdańsk & $\mathbf{1 9 , 9 7}$ & 31,2 & 31,94 & 19,9 \\
\hline Gdynia & $\mathbf{6 3 , 2 7}$ & $\mathbf{7 8 , 3 2}$ & $\mathbf{8 0 , 8 8}$ & $\mathbf{6 6 , 8 9}$ \\
\hline Gliwice & $\mathbf{2 0 , 8 4}$ & 29,22 & 30,75 & $\mathbf{4 1 , 1 6}$ \\
\hline Jaworzno & 3,64 & 15,49 & 28,92 & 20,43 \\
\hline Kielce & $-3,20$ & $\mathbf{5 1 , 3 3}$ & $\mathbf{4 2 , 6}$ & $\mathbf{3 4 , 7 9}$ \\
\hline Kraków & $-2,09$ & 16,11 & 7,09 & 12,23 \\
\hline Krosno & $-0,80$ & $\mathbf{6 0 , 5 6}$ & $\mathbf{6 0 , 2 7}$ & $\mathbf{4 6 , 8 2}$ \\
\hline Legnica & $\mathbf{2 5 , 0 6}$ & 39,22 & $\mathbf{4 9 , 8 1}$ & 18,45 \\
\hline Przemyśl & 0,26 & $\mathbf{4 5 , 8 3}$ & 33,38 & 8,77 \\
\hline Rzeszów & $\mathbf{2 0 , 3 7}$ & $\mathbf{5 8 , 2}$ & 18,39 & $\mathbf{4 3 , 8 7}$ \\
\hline Sopot & $\mathbf{3 9 , 8 0}$ & 38,12 & 0,11 & 24,71 \\
\hline Świnoujście & 2,50 & 36,17 & $\mathbf{4 2 , 2 1}$ & $\mathbf{3 9 , 3 7}$ \\
\hline Toruń & 1,49 & $\mathbf{5 1 , 9 1}$ & $\mathbf{4 4 , 7 0}$ & $\mathbf{5 2 , 9 3}$ \\
\hline Tychy & 7,90 & 12,49 & 32,58 & $\mathbf{4 6 , 0 0}$ \\
\hline Wrocław & $\mathbf{1 4 , 5 9}$ & $\mathbf{7 7 , 0 5}$ & $\mathbf{6 0 , 6 2}$ & 16,57 \\
\hline Żory & 0,98 & 13,56 & $\mathbf{4 5 , 8 7}$ & 19,13 \\
\hline Średnia & $\mathbf{1 2 , 3 8}$ & $\mathbf{4 1 , 9 3}$ & $\mathbf{3 9 , 7 9}$ & $\mathbf{3 1 , 5 7}$ \\
\hline
\end{tabular}

Zaznaczono wartości powyżej średniej poparcia w danym roku.

Źródło: opracowanie własne na podstawie danych zawartych na www.pkw.gov.pl.

Tylko jednak jeden prezydent spośród 17 analizowanych tutaj osiągał zawsze ponadśrednie wartości WR1, choć należy podkreślić, że były one najwyższe (W. Szczurek): w 2010 roku różnica w poparciu pomiędzy włodarzem Gdyni 
a jego głównym konkurentem osiągnęła rekordowy pułap 80,88 (!). W czterech miastach, w trzech kolejnych wyborach, ich włodarze odnotowali wartości WR1 ponad średnie, przy czym w latach 2006-2014 były to Kielce, Krosno i Toruń, a w latach 2002-2010 - Wrocław. Warto też zwrócić uwagę na przypadek Krakowa - to jedyne miasto, w którym wartość WR1 jego włodarza osiąga zawsze wyraźnie niższy pułap od średniej, a pomimo to prezydent J. Majchrowski zawsze jednak wygrywa (choć w II turze) ${ }^{15}$.

Wydaje się, że wartość 50 WR1 to pułap, który można przyjąć jako znaczący. Bo o ile nierzadko zdarza się, że wieczni prezydenci zdobywają poparcie ponad $50 \%$, to osiągnięcie przewagi o 50 p.p. nad głównym rywalem stanowić może o szczególnie silnej pozycji politycznej. W 2002 roku, taki poziom WR1 przekroczył tylko W. Szczurek $(63,27)$. W 2006 roku prezydentów spełniających to kryterium można wyróżnić już siedmiu: W. Szczurek (78,32), R. Dutkiewicz (77,05), R. Przytocki $(60,56)$, T. Ferenc $(58,2)$, J. Krywult (57,98), M. Zaleski $(51,91)$, W. Lubawski $(51,33)$. Z kolei w elekcji w 2010 roku próg ten przekroczyli prezydenci 4 miast: Gdyni $(80,88)$, Bielska-Białej $(66,24)$, Wrocławia $(60,62)$ oraz Krosna $(60,27)$. Wybory w 2014 roku przyniosły dalszy spadek liczebności tej grupy prezydentów, ponieważ wartość powyżej 50 WR1 odnotowali tylko włodarze Gdyni $(66,89)$ oraz Torunia $(52,93)$.

Adekwatnie do WR1, w odniesieniu do komitetów startujących w wyborach do rady miasta, można wyodrębnić wskaźnik intensyfikacji rywalizacji wyborczej pomiędzy komitetem prezydenta a komitetem jego największego rywala (WR1K). Można go obliczyć na podstawie różnicy między poparciem (w \%) uzyskanym przez komitet prezydenta i komitet jego głównego rywala w wyborach do rady miasta (szerzej o jego zastosowaniu - niżej).

Kolejny czynnik - wskaźnik związku z zapleczem (WZ) - pozwala określić jak wygląda poparcie osoby ubiegającej się o stanowisko wybieralne na tle poparcia dla ugrupowania, które reprezentuje. W przypadku wyborów prezydenta miasta indykator ten wylicza się na podstawie ilorazu procentowego poparcia włodarza i poparcia, które uzyskał jego komitet w wyborach do RM. Przyjmuje się, że prezydent miasta (i generalnie osoby kandydujące na to stanowisko) powinny cieszyć się większym poparciem personalnym niż ugrupowanie, z którego

15 Może to świadczyć z jednej strony o dużym stopniu rywalizacyjności wyborów prezydenckich a $\mathrm{z}$ drugiej strony o słabej woli do zawarcia konsensusu pomiędzy rywalami J. Majchrowskiego. Wydaje się również, że decydującym czynnikiem w przypadku Krakowa jest mała rywalizacyjność i wysokie upartyjnienie wyborów do RM - mandaty radnych zdobywają z reguły 3 ugrupowania (w tym zdecydowaną większość PO i PiS), co przy dużej liczbie miejsc w krakowskiej radzie (43) jest swoistym paradoksem. 
startują (które ich popiera). Innymi słowy, iloraz ten powinien przyjąć wartość powyżej 1,0. Przeciwny przypadek - wartość $<1,0$ oznacza, że dany kandydat ma mniejsze poparcie aniżeli komitet, który go wystawia, co może świadczyć o pewnej słabości kandydata.

Sytuacja gdy $\mathrm{WZ}<1,0$ oznacza bowiem, że na kandydata głosowało mniej osób niż na jego komitet w wyborach do RM. Gdy natomiast wskaźnik związku wiecznego prezydenta z zapleczem przyjmuje wartość powyżej 1,0 to wiadomo, że wśród głosujących na niego znaleźli się także wyborcy głosujący na konkurencyjne ugrupowania do rady miasta. Teoretycznie można zatem byłoby przyjąć, że im wyższa jest wartość WZ prezydenta miasta, tym ma on silniejszą pozycję polityczną. Nie zawsze taki wniosek jest jednak uzasadniony.

Paradoksalnie bowiem, WZ o dużej wartości wcale nie musi oznaczać silnej pozycji politycznej, lecz świadczy raczej o mocnej pozycji w swoim ugrupowaniu. Przypadek Krakowa w 2002 roku pokazuje ten paradoks - WZ J. Majchrowskiego osiągnął wówczas rekordową wartość 5,88 (najwięcej spośród badanych włodarzy we wszystkich elekcjach), a WR1 oraz WR1K przyjęły

Tabela 4. Wartości WZ i WR1K w elekcjach wiecznych prezydentów w latach 2002-2014 (I tury)

\begin{tabular}{|l|r|r|l|r|r|l|l|l|l|l|r|r|}
\hline \multicolumn{9}{|c|}{2002} & \multicolumn{9}{c|}{2006} & \multicolumn{3}{c|}{2010} & \multicolumn{3}{c|}{2014} \\
\hline \multicolumn{1}{|c|}{ Miasto } & WZ & WR1K & \multicolumn{1}{|c|}{ Miasto } & WZ & WR1K & Miasto & WZ & WR1K & Miasto & WZ & WR1K \\
\hline Kraków & 5,88 & $-8,81$ & Kraków & 3,79 & $-17,46$ & Kraków & 2,78 & $-27,73$ & Kielce & 3,42 & 1,59 \\
\hline Krosno & 2,06 & $-18,46$ & Wrocław & 3,42 & 22,58 & Sopot & 2,59 & $-12,80$ & Toruń & 3,08 & 11,13 \\
\hline Toruń & 1,90 & $-5,10$ & Kielce & 3,17 & 1,35 & Toruń & 2,44 & $-6,46$ & Kraków & 2,92 & $-19,75$ \\
\hline Tychy & 1,88 & $-7,76$ & Legnica & 3,05 & 0,02 & Przemyśl & 2,33 & $-5,03$ & Bielsko B. & 2,56 & 7,32 \\
\hline Bielsko B. & 1,82 & $-12,77$ & Bielsko B. & 2,98 & $-2,54$ & Kielce & 2,30 & 7,40 & Tychy & 2,29 & 12,49 \\
\hline Przemý́l & 1,79 & $-1,16$ & Toruń & 2,97 & 18,75 & Jaworzno & 2,28 & 2,83 & Legnica & 2,15 & $-2,48$ \\
\hline Gliwice & 1,72 & 1,46 & Tychy & 2,36 & 0,82 & Bielsko B. & 2,26 & 22,46 & Jaworzno & 1,90 & $-6,63$ \\
\hline Rzeszów & 1,53 & 16,08 & Świnoujście & 2,02 & 16,78 & Legnica & 2,20 & 5,13 & Rzeszów & 1,78 & $-0,30$ \\
\hline Gdynia & 1,47 & 33,86 & Jaworzno & 1,96 & $-6,24$ & Żory & 2,01 & 15,14 & Świnoujście & 1,75 & 16,13 \\
\hline Gdańsk & 1,39 & 9,73 & Krosno & 1,84 & 15,17 & Tychy & 1,86 & 11,75 & Przemyś1 & 1,71 & $-5,16$ \\
\hline Kielce & 1,38 & $-11,30$ & Rzeszów & 1,80 & 14,05 & Krosno & 1,84 & 17,78 & Gliwice & 1,68 & 10,21 \\
\hline Legnica & 1,36 & 15,71 & Gdynia & 1,75 & 32,60 & Wrocław & 1,71 & 15,56 & Żory & 1,63 & 5,02 \\
\hline Sopot & 1,25 & 30,70 & Przemyśl & 1,60 & 16,13 & Gliwice & 1,63 & $-2,01$ & Krosno & 1,62 & 14,12 \\
\hline Wrocław & 1,23 & 9,78 & Gliwice & 1,45 & 17,90 & Rzeszów & 1,63 & 1,64 & Gdynia & 1,60 & 29,10 \\
\hline Żory & 1,22 & 5,43 & Żory & 1,43 & $-1,50$ & Świnoujście & 1,62 & 15,10 & Wrocław & 1,12 & 10,55 \\
\hline Świnoujście & 1,14 & 14,06 & Sopot & 1,39 & 22,84 & Gdynia & 1,51 & 37,24 & Sopot & 1,08 & 26,03 \\
\hline Jaworzno & 1,02 & $-5,32$ & Gdańsk & 1,12 & 25,91 & Gdańsk & 0,97 & 32,16 & Gdańsk & 0,95 & 18,85 \\
\hline Średnia & 1,77 & 3,89 & & 2,24 & 10,42 & & 2,0 & 7,66 & & 1,96 & 7,54 \\
\hline
\end{tabular}

Uszeregowano od największych wartości WZ dla danej elekcji.

Źródło: opracowanie własne na podstawie danych zawartych na www.pkw.gov.pl. 
wartości ujemne, odpowiednio: $-2,09$ oraz -8,81. Wynikał z tych danych wniosek prosty - komitet J. Majchrowskiego miał mniejsze poparcie od komitetu jego największego rywala, a niezwykle wysoka wartość WZ w tym konkretnym przypadku oznaczała słabą pozycję ugrupowania J. Majchrowskiego. Wydaje się dlatego, że dla prawidłowości analizowania WZ należy jego wartości komparować z wartością WR1K - w przypadku, gdy ta ostania przyjmuje ujemny charakter, to tej pierwszej nie można przypisywać zbyt dużego wpływu na pozycję polityczną włodarza. Poniżej zestawiono wartości WZ i WR1K (tab. 4).

Wyraźnie widać, że ujemnej wartości WR1K zazwyczaj towarzyszy wysoki WZ. Tylko w trzech przypadkach przy wartości WR1K poniżej zera odnotowano stosunkowo niską wartość WZ (Jaworzno 2002 r. - 1,02; Kielce 2002 r. - 1,38; Żory 2006 r. - 1,43). W pozostałych przypadkach wyraźnie słabszej pozycji komitetów prezydenckich w stosunku do głównego ugrupowania konkurencyjnego (WR1K < 0) towarzyszył silny status prezydenta - WZ przybierał wartość nie mniejszą niż ok. 1,6.

Gdy chodzi o wskaźnik rywalizacyjności pomiędzy komitetem wiecznego prezydenta a ugrupowaniem głównego rywala w wyborach do rady, to można zauważyć dużą dysproporcję z indykatorem rywalizacyjności personalnej. O ile bowiem wartości WR1 przekraczają, jak wspominano wyżej, poziom 50,00 to w przypadku WR1K nie odnotowano nigdy takiego pułapu. Największa różnica w poparciu komitetu prezydenta i ugrupowania rywala z rzadka przekraczała wartość 30,00 - w analizowanych miastach, na 64 elekcje lat 2002-2014 zdarzyło się to tylko pięciokrotnie: w Gdyni (2002, 2006, 2010), w Sopocie (2002) i Gdańsku (2006). Średnie wartości tego wskaźnika są również wyraźnie niższe od średnich WR1 (porównanie WR1 i WR1K zaprezentowano w tab. 5).

Na podstawie danych zawartych w tabeli 5 można także zauważyć inną zależność - z wyjątkiem dwóch przypadków (z 64) wieczni prezydenci zawsze mieli większą przewagę nad głównymi rywalami niż ich komitety nad ugrupowaniami rywali. Tylko w Świnoujściu w 2002 roku oraz Sopocie w 2014 roku odnotowano odwrotną sytuację ${ }^{16}$, jednak w obydwu przypadkach komitety tych

16 W 2002 r. przewaga prezydenta J. Żmurkiewicza nad konkurentem (Stanisław Możejko) była znacznie skromniejsza (WR1 $=2,5$ ) niż SLD-UP nad komitetem Możejki (KWW Świnoujście.pl - WR1K = 14,6). Z kolei w Sopocie w 2014 r. przewaga J. Karnowskiego nad Grażyną Czajkowską wynosiła 24,71, podczas gdy przewaga jego komitetu (KWW Platforma Sopocian Jacka Karnowskiego) nad KWW Kocham Sopot konkurentki wyniosła 26,03. 
włodarzy miały charakter partyjny ${ }^{17}$. Nie może jednak dziwić silniejsza pozycja wiecznych prezydentów niż ich ugrupowań - rywalizacja polityczna jest w Polsce silnie upartyjniona, czego rezultatem jest także silne odzwierciedlanie preferencji partyjnych w wyborach samorządowych do rad. Z kolei w silnie spersonalizowanej rywalizacji o fotele prezydentów miast ich mieszkańcy bardziej zwracają uwagę na dokonania włodarzy niż na szyldy ugrupowań, które ich popierają.

Tabela 5. Wartości WR1 i WR1K w elekcjach wiecznych prezydentów w latach 2002-2014 (I tury)

\begin{tabular}{|l|r|r|l|r|r|l|l|l|l|l|r|r|}
\hline \multicolumn{9}{|c|}{2002} & \multicolumn{3}{|c|}{2006} & \multicolumn{3}{c|}{2010} & \multicolumn{3}{c|}{2014} \\
\hline \multicolumn{1}{|c|}{ Miasto } & WR1 & WR1K & \multicolumn{1}{|c|}{ Miasto } & WR1 & WR1K & Miasto & WR1 & WR1K & Miasto & WR1 & WR1K \\
\hline Bielsko B. & $-4,12$ & $-12,77$ & Bielsko B. & 57,98 & $-2,54$ & Bielsko B. & 66,24 & 22,46 & Bielsko B. & 24,64 & 7,32 \\
\hline Gdańsk & 19,97 & 9,73 & Gdańsk & 31,20 & 25,91 & Gdańsk & 31,94 & 32,16 & Gdańsk & 19,90 & 18,85 \\
\hline Gdynia & 63,27 & 33,86 & Gdynia & 78,32 & 32,60 & Gdynia & 80,88 & 37,24 & Gdynia & 66,89 & 29,10 \\
\hline Gliwice & 20,84 & 1,46 & Gliwice & 29,22 & 17,90 & Gliwice & 30,75 & $-2,01$ & Gliwice & 41,16 & 10,21 \\
\hline Jaworzno & 3,64 & $-5,32$ & Jaworzno & 15,49 & $-6,24$ & Jaworzno & 28,92 & 2,83 & Jaworzno & 20,43 & $-6,63$ \\
\hline Kielce & $-3,20$ & $-11,30$ & Kielce & 51,33 & 1,35 & Kielce & 42,60 & 7,40 & Kielce & 34,79 & 1,59 \\
\hline Kraków & $-2,09$ & $-8,81$ & Kraków & 16,11 & $-17,46$ & Kraków & 7,09 & $-27,73$ & Kraków & 12,23 & $-19,75$ \\
\hline Krosno & $-0,80$ & $-18,46$ & Krosno & 60,56 & 15,17 & Krosno & 60,27 & 17,78 & Krosno & 46,82 & 14,12 \\
\hline Legnica & 25,06 & 15,71 & Legnica & 39,22 & 0,02 & Legnica & 49,81 & 5,13 & Legnica & 18,45 & $-2,48$ \\
\hline Przemyśl & 0,26 & $-1,16$ & Przemyśl & 45,83 & 16,13 & Przemyś1 & 33,38 & $-5,03$ & Przemyś1 & 8,77 & $-5,16$ \\
\hline Rzeszów & 20,37 & 16,08 & Rzeszów & 58,20 & 14,05 & Rzeszów & 18,39 & 1,64 & Rzeszów & 43,87 & $-0,30$ \\
\hline Sopot & 39,80 & 30,70 & Sopot & 38,12 & 22,84 & Sopot & 0,11 & $-12,80$ & Sopot & 24,71 & $\mathbf{2 6 , 0 3}$ \\
\hline Świnoujście & $\mathbf{2 , 5 0}$ & $\mathbf{1 4 , 0 6}$ & Świnoujście & 36,17 & 16,78 & Świnoujście & 42,21 & 15,10 & Świnoujście & 39,37 & 16,13 \\
\hline Toruń & 1,49 & $-5,10$ & Toruń & 51,91 & 18,75 & Toruń & 44,70 & $-6,46$ & Toruń & 52,93 & 11,13 \\
\hline Tychy & 7,90 & $-7,76$ & Tychy & 12,49 & 0,82 & Tychy & 32,58 & 11,75 & Tychy & 46,00 & 12,49 \\
\hline Wrocław & 14,59 & 9,78 & Wrocław & 77,05 & 22,58 & Wrocław & 60,62 & 15,56 & Wrocław & 16,57 & 10,55 \\
\hline Żory & 0,98 & 5,43 & Żory & 13,56 & $-1,50$ & Żory & 45,87 & 15,14 & Żory & 19,13 & 5,02 \\
\hline Średnia & 12,38 & 3,89 & & 41,93 & 10,42 & & 39,79 & 7,66 & & 31,57 & 7,54 \\
\hline
\end{tabular}

Uszeregowano alfabetycznie.

Źródło: opracowanie własne na podstawie danych zawartych na www.pkw.gov.pl.

Reasumując ten wątek, należy stwierdzić, że wskaźnik związku z zapleczem może nie odzwierciedlać realnej pozycji politycznej wiecznego prezydenta na lokalnej scenie politycznej, o ile przyjmuje on wysoką wartość przy równoczesnej ujemnej wartości WR1K. Co więcej, należy podkreślić, że ten drugi wskaźnik ma o wiele większe znacznie dla pomiaru pozycji politycznej włodarza

17 J. Żmurkiewicz zawsze kandyduje z SLD. J. Karnowski w 2014 r. startował z komitetu niby-bezpartyjnego - na jego silne powiązanie z określoną partią parlamentarną wskazywał już termin ,platforma” użyty w nazwie komitetu. 
miasta, ponieważ jego wysoka wartość przekłada się na dysponowanie dużą, własną reprezentacją w radzie. Widać to na przykładzie prezydenta Gdyni, który miał zawsze jedno z najniższych WZ przy każdorazowym najwyższym WR1K (w 2014 r. - 29,1; we wcześniejszych elekcjach powyżej 32,6). Wartość WZ pokazuje bowiem zawsze pozycję wewnętrzną włodarza miasta (na tle własnego ugrupowania), a tylko w pewnych sytuacjach jest równocześnie indykatorem pozwalającym określać jego pozycję na lokalnej scenie politycznej.

W przyjętym na początku rozumieniu pojęcia „pozycja polityczna” zwrócono uwagą na kwestię decyzyjności, a raczej możliwości podejmowania efektywnych decyzji. W przypadku prezydenta miasta ta „decyzyjność” jest powiązana z własnym lub koalicyjnym zapleczem politycznym w radzie miasta. Włodarz miasta, który takiego stabilnego zaplecza nie ma w zasadzie nie może liczyć na sprawność decyzyjną, podejmowane przez niego procesy decyzyjne będą napotykały opór bądź obstrukcję opozycyjnych względem niego radnych ${ }^{18}$. Z tego punktu widzenia niezwykle istotnymi wskaźnikami poziomu pozycji politycznej wiecznego prezydenta są indykatory PRM (pozycja jego komitetu w radzie miasta) i MRM (procent mandatów zdobytych w radzie przez tenże). Zebrano je w tabeli 6 .

Po pierwszych bezpośrednich wyborach prezydentów ich ugrupowania zdobyły najwięcej mandatów w radach 8 miast (Gdańsk, Gdynia, Legnica, Rzeszów, Sopot, Świnoujście, Wrocław i Żory), jednak tylko w dwóch z nich ugrupowania te zajęły więcej niż połowę miejsc w radach (Gdynia - 75\% miejsc, Sopot - 62\%). Po czterech latach również w 8 miastach największe poparcie miały komitety wiecznych prezydentów, a w czterech z nich zdobyły ponad 50\% mandatów (Gdańsk - 62\%, Gdynia - 61\%, Przemyśl i Rzeszów - po 52\%). W 2010 roku komitety prezydenckie w aż 12 miastach zdobyły najwięcej miejsc radnych, a w czterech zdobyły większość absolutną (Gdańsk - 76\%, Gdynia - 75\%, Krosno - 52\% i Wrocław - 51\%). Cztery lata później ponownie większość wiecznych prezydentów wprowadziła najwięcej radnych (11 miast), w pięciu z nich zdobyła większość bezwzględną mandatów radnych (Gdańsk - 65\%, Gdynia - 61\%, Krosno i Wrocław - po $57 \%$ i Sopot - 62\%).

18 Choć trzeba przyznać, że w praktyce pojawiały się przykłady prezydentów miast, którzy nie posiadając większości $\mathrm{w}$ radach sprawowali władzę na tyle skutecznie, że w kolejnych wyborach dokonywali reelekcji np. M. Kobyliński w Słupsku czy J. Majchrowski. 
Tabela 6. Porównanie wskaźników PRM (pozycja ugrupowania prezydenta w radzie miasta - zajmowane w jej strukturze miejsce ze względu na liczbę mandatów)

i MRM (procent mandatów zdobytych w radzie przez komitet prezydencki) w miastach wiecznych prezydentów

\begin{tabular}{|l|c|c|c|c|c|c|c|c|}
\hline \multirow{2}{*}{ Miasto } & \multicolumn{2}{|c|}{ Wybory 2002} & \multicolumn{2}{c|}{ Wybory 2006 } & \multicolumn{2}{c|}{ Wybory 2010 } & \multicolumn{2}{c|}{ Wybory 2014 } \\
\cline { 2 - 10 } & PRM & MRM & PRM & MRM & PRM & MRM & PRM & MRM \\
\hline Bielsko-Biała & $7 / 7$ & 4 & $3 / 4$ & 24 & $\mathbf{1 / 4}$ & 44 & $2 / 4$ & 20 \\
\hline Gdańsk & $\mathbf{1 / 6}$ & 44 & $\mathbf{1 / 2}$ & $\mathbf{6 2}$ & $\mathbf{1 / 3}$ & $\mathbf{7 6}$ & $\mathbf{1 / 2}$ & $\mathbf{6 5}$ \\
\hline Gdynia & $1 / 3$ & 75 & $1 / 3$ & 61 & $1 / 3$ & 75 & $1 / 3$ & 61 \\
\hline Gliwice & $2 / 4$ & 36 & $\mathbf{1 / 4}$ & 48 & $2 / 4$ & 36 & $\mathbf{1 / 4}$ & 40 \\
\hline Jaworzno & $2 / 2$ & 48 & $2 / 4$ & 26 & $\mathbf{1 / 4}$ & 30 & $3 / 4$ & 30 \\
\hline Kielce & $2 / 4$ & 32 & $3 / 4$ & 21 & $\mathbf{1 / 5}$ & 28 & $3 / 6$ & 16 \\
\hline Kraków & $0 / 6$ & 0 & $3 / 3$ & 5 & $3 / 3$ & 16 & $3 / 3$ & 14 \\
\hline Krosno & $4 / 5$ & 10 & $\mathbf{1 / 4}$ & 48 & $\mathbf{1 / 3}$ & $\mathbf{5 2}$ & $\mathbf{1 / 4}$ & $\mathbf{5 7}$ \\
\hline Legnica & $\mathbf{1 / 6}$ & 48 & $3 / 6$ & 20 & $\mathbf{1 / 5}$ & 36 & $3 / 4$ & 17 \\
\hline Przemyś1 & $2 / 6$ & 22 & $\mathbf{1 / 4}$ & $\mathbf{5 2}$ & $2 / 5$ & 26 & $3 / 4$ & 17 \\
\hline Rzeszów & $\mathbf{1 / 5}$ & 40 & $\mathbf{1 / 5}$ & $\mathbf{5 2}$ & $\mathbf{1 / 3}$ & 44 & $\mathbf{1 / 3}$ & 44 \\
\hline Sopot & $\mathbf{1 / 3}$ & $\mathbf{6 2}$ & $\mathbf{1 / 4}$ & 43 & $4 / 4$ & 10 & $1 / 3$ & 62 \\
\hline Świnoujście & $\mathbf{1 / 5}$ & 43 & $\mathbf{1 / 8}$ & 29 & $\mathbf{1 / 5}$ & 48 & $\mathbf{1 / 4}$ & 43 \\
\hline Toruń & $4 / 5$ & 14 & $3 / 4$ & 21 & $2 / 4$ & 25 & $\mathbf{1 / 4}$ & 28 \\
\hline Tychy & $4 / 5$ & 16 & $3 / 6$ & 24 & $\mathbf{1 / 5}$ & 36 & $\mathbf{1 / 4}$ & 28 \\
\hline Wrocław & $\mathbf{1 / 4}$ & 47 & $3 / 4$ & 27 & $\mathbf{1 / 4}$ & $\mathbf{5 1}$ & $\mathbf{1 / 4}$ & $\mathbf{5 7}$ \\
\hline Żory & $\mathbf{1 / 3}$ & 43 & $3 / 5$ & 26 & $\mathbf{1 / 4}$ & 39 & $\mathbf{1 / 4}$ & 30 \\
\hline
\end{tabular}

Uszeregowano alfabetycznie.

Źródło: opracowanie własne na podstawie danych zawartych na www.pkw.gov.pl.

Tak więc uznając wybory w 2006 roku za pierwszą reelekcję wiecznych prezydentów można stwierdzić, że ich ponownym zwycięstwom w rywalizacji wyborczej w znaczącej liczbie miast towarzyszy zdobywanie większości zwykłej w radach, choć osiąganie większości absolutnej mandatów nie zdarza się już tak często. Ponadto, gdy opcja prezydencka zdobywa już większość miejsc radnych, to z reguły dotyczy to prezydentów oficjalnie bądź nieoficjalnie powiązanych z konkretną partią parlamentarną (Gdańsk i Sopot - PO; Rzeszów - SLD; Przemyśl - PiS). Są oczywiście wyjątki - Krosno, a zwłaszcza Gdynia - w których komitety prezydenckie są silne autorytetem swoich liderów, a nie szyldów partyjnych. 


\section{Zakończenie}

Spośród wziętych do analizy wskaźników pozycji politycznej wiecznych prezydentów, największe znaczenie wydają się mieć WR1, WR1K oraz MRM. Stopień rywalizacyjność wyborów - zarówno w odniesieniu do elekcji prezydentów, jak i ich komitetów w wyborach radnych - pozwala dość dokładnie określić siłę polityczną wiecznego prezydenta. Analiza pokazała, że w przypadku niskiego poziomu rywalizacyjności wyborów wieczny prezydent ma silniejszą pozycję na lokalnej scenie politycznej, która zwiększa jego szanse na kolejną reelekcję. Podobnie liczba mandatów radnych ugrupowania prezydenta determinuje w sposób znaczący jego możliwości decyzyjne.

Z kolei przyznając największe znaczenie wspomnianym wyżej indykatorom można dostrzec, że WR1 > 50 zawsze w wyborach bezpośrednich osiągał W. Szczurek w Gdyni. Dwukrotnie ten pułap przekraczali prezydenci Bielska Białej, Krosna, Torunia i Wrocławia, a jeden raz - Kielc, Legnicy i Rzeszowa. Wartość WR1K > 20 w czterech elekcjach lat 2002-2014 osiągało tylko ugrupowanie lokalne prezydenta Gdyni, trzykrotnie udawało się to komitetowi prezydenta Sopotu ${ }^{19}$, a jednokrotnie prezydentom Bielska-Białej, Gdańska i Wrocławia. Z kolei MRM powyżej 50\% zawsze w elekcjach lat 2002-2014 odnotowywano w Gdyni, trzykrotnie - w Gdańska, dwukrotnie - w Krośnie, Sopocie i Wrocławiu, a jednokrotnie - w Przemyślu i Rzeszowie. Jak widać, z 17 wiecznych prezydentów najsilniejszą pozycję polityczną w latach 2002-2014 wydawał się mieć prezydent Gdyni; w jego przypadku analizowane wskaźniki były zawsze spełniane na najwyższym poziomie. Biorąc pod uwagę różne wskaźniki i różne elekcje, jako stosunkowo silną można określić pozycję polityczną prezydentów Gdańska, Sopotu, Kielc, Krosna, Rzeszowa, Świnoujścia i Torunia.

Można też dostrzec związek między pozycją polityczną a powiązaniami włodarzy z partiami politycznymi. Wydaje się, że jest ona mocniejsza, gdy wieczni prezydenci zachowują charakter pozapartyjny lub gdy maskują swoje koneksje partyjne (niby-bezpartyjność). Przypadki silnej pozycji ,jawnie” partyjnych prezydentów są nieliczne, w zasadzie z wyżej wymienionych jako egzemplifikację można tylko podać włodarzy Gdańska i Świnoujścia.

Trzeba jednak pamiętać, że przecież wielokadencyjność już sama w sobie jest potwierdzeniem mocnej pozycji wiecznych prezydentów. Analizowane

19 Warto jednak wspomnieć, że komitet ten startował w kolejnych latach pod różnymi nazwami i charakteryzował się partyjną, niby-bezpartyjną lub lokalną specyfiką. 
wskaźniki w kolejnych elekcjach przybierały jednak wartości nieco niższe, co może stanowić symptom osłabiania, póki co dość silnej, pozycji wiecznych prezydentów.

\section{Bibliografia}

Antoszewski Andrzej, Istota władzy samorzadowej, w: Ganowicz Ewa, Rubisz Lech (red.), Polityka lokalna. Właściwości, determinanty, podmioty, Wydawnictwo Adam Marszałek, Toruń 2008.

Dahl Robert A., Stinebrickner Bruce, Współczesna analiza polityczna, Scholar, Warszawa 2007.

Drzonek Maciej, Partie w masce niepartyjności - uwagi o komitetach niby-bezpartyjnych w elekcjach prezydentów miast, w: Partyjnie czy bezpartyjnie? Szkice o zdobywaniu władzy lokalnej, red. idem, Wydawnictwo Naukowe Uniwersytetu Szczecińskiego, Szczecin 2014.

Drzonek Maciej, Reelekcje prezydentów miast w wyborach bezpośrednich w Polsce, Dante, Kraków 2013.

Gajowniczek Tomasz, Rywalizacja w wyborach powiatowych województwa warmińsko -mazurskiego, w: Doświadczenia i perspektywy rozwoju samorzadu terytorialnego i zawodowego, red. Paweł Antkowiak, Wydawnictwo Adam Marszałek, Toruń 2014.

Gendźwiłł Adam, Żółtak Tomasz, Bezpartyjność w powolnym odwrocie. Analiza rozpowszechniania bezpartyjności w wyborach lokalnych w Polsce w latach 2002-2010, „Studia Regionalne i Lokalne” 2012, nr 1.

Glajcar Rafał, Podmioty rywalizacji wyborczej w miastach na prawach powiatu (na przykładzie województwa ślaskiego), w: Wybory samorządowe 2010, red. Mariusz Kolczyński, Waldemar Wojtasik, Remar, Katowice 2011.

Maty Rocznik Statystyczny Polski 2003, GUS, Warszawa 2003.

Maty Rocznik Statystyczny Polski 2008, GUS, Warszawa 2008.

Matyja Rafał, Rywalizacja polityczna w Polsce, Ośrodek Myśli Politycznej, Wyższa Szkoła Informatyki i Zarządzania, Kraków-Rzeszów 2013.

Pietraś Ziemowit J., Decydowanie polityczne, Wydawnictwo Naukowe PWN, WarszawaKraków 1998. 
Rocznik statystyczny Rzeczypospolitej Polskiej 2012, GUS, Warszawa 2012.

Swianiewicz Paweł, Bezpartyjni radni w samorzadach gminnych, „Samorząd Terytorialny" 2010, nr 11.

Wojtasik Waldemar, Funkcje wyborów w III RP, Wydawnictwo Uniwersytetu Śląskiego, Katowice 2012.

\title{
Streszczenie
}

Od 2002 roku w wyborach samorządowych prezydenci miast są wybierani w sposób bezpośredni. W 17 miastach na prawach powiatu te same osoby wybierano czterokrotnie (w wyborach w 2002, 2006, 2010, 2014 r.). Określa się ich mianem „wiecznych prezydentów" (wielokadencyjni prezydenci). W artykule wyodrębniono i uogólniono wskaźniki, które pozwalają na określenie ich pozycji politycznej na lokalnych scenach politycznych.

Słowa kluczowe: polityka lokalna, wybory prezydentów miast, wielokadencyjni prezydenci, władza lokalna

\section{INDICATORS IN RESEARCH OF MULTI-TERMS MAYORS' POLITICAL POSITION}

\begin{abstract}
Since 2002 in Poland the mayors of towns there have been elected in direct elections. In 17 towns with county rights the same persons were chosen for the four times (elections of the years 2002, 2006, 2010, 2014). They are so called "everlasting mayors" (multi-term mayors, incumbents). Their successes are the starting point to determine and generalize the indicators that can define their political position on the local political scenes.
\end{abstract}

Keywords: local politics, the mayor of town' elections, multi-term mayors, local power 
